\title{
DISTANCE AND TIME OF WATER EFFLUENCE ON SOIL SURFACE AFTER FAILURE OF BURIED WATER PIPE. LABORATORY INVESTIGATIONS AND STATISTICAL ANALYSIS
}

\section{ODLEGŁOŚĆ I CZAS WYPŁYWU WODY NA POWIERZCHNIĘ TERENU PO AWARII PODZIEMNEGO WODOCIĄGU. BADANIA LABORATORYJNE I ANALIZY STATYSTYCZNE}

\begin{abstract}
One solution to limit the inconvenience caused by suffosion processes following pipe breakages is retaining so-called protection zones near the pipes, the utilization of which would be handled by the system operator. Due to the fact that to determine the size of such zones is a challenging task, the analysis should be performed gradually, based on successive field studies, laboratory and numerical research. The present article is the outcome of the first stage of the laboratory research eventually aiming at the determination of the protection zone around a potential leakage in a water supply pipe. The first stage of the investigations was devoted to (1) the assessment of an average distance between the place of water effluence on the soil surface and the place of the water failure for 4 different areas of leak and 11 values of hydraulic pressure head in the pipe, (2) the initiatory assessment of the protection zone dimensions for analysed soil conditions, (3) the analysis of dependence between the time of water effluence on the soil surface after a failure of a buried water pipe and the leak area as well as the hydraulic pressure head in the pipe. The scope of the works comprises laboratory study and statistical analysis. The research was carried out preserving geometrical and kinematic similarity. The obtained results should be considered initial, oriented towards further stages of laboratory research comprising dynamic similarity.
\end{abstract}

Keywords: water supply, breakage, maintenance, water effluence.

\begin{abstract}
Jedna z propozycji ograniczenia uciążliwości spowodowanych zjawiskami sufozyjnymi po awarii wodociagu jest zachowanie w poblizu przewodów tzw. stref ochronnych, o zagospodarowaniu których decydowałby eksploatator sieci. Określenie wymiarów takich stref jest bardzo trudnym zadaniem, dlatego stosowne analizy powinny odbywać się stopniowo, na bazie kolejnych etapów badań terenowych, laboratoryjnych i numerycznych. W ramach niniejszej pracy przedstawiono wyniki pierwszego etapu badań laboratoryjnych, których ostatecznym celem jest wyznaczenie strefy ochronnej wokót ewentualnej nieszczelności rury wodociagowej. Pierwszy etap badań objąt określenie przeciętnej odległości wyplywu wody na powierzchnię terenu od miejsca awarii podziemnego wodociagu dla 4 różnych powierzchni nieszczelności przewodu oraz 11 wysokości ciśnień w przewodzie, wstępne oszacowanie wielkości strefy ochronnej dla analizowanych warunków gruntowych oraz analize zależności między czasem wypływu wody na powierzchnię terenu po awarii podziemnego wodociagu a powierzchnia nieszczelności $i$ wysokościa ciśnienia $w$ przewodzie. Zakres pracy obejmowat badania laboratoryjne $i$ analizy statystyczne. Badania przeprowadzono z zachowaniem podobieństwa geometrycznego i kinematycznego. Uzyskane wyniki należy więc traktować jako wstępne, ukierunkowujące dalsze etapy badań laboratoryjnych, uwzględniające również podobieństwo dynamiczne.
\end{abstract}

Stowa kluczowe: wodociag, awaria, eksploatacja, wyplyw wody.

\section{Introduction}

The use of water supply pipes all over the world has always been accompanied by breakages and leakages. What can reduce a number of damages is skilful management of a water supply system and proper maintenance. It is, however, impossible to entirely eliminate such incidents as, most often, they occur randomly $[5,7,24]$. They can result in financial and social losses [7, 8, 25, 28]. Moreover, leakages can pose a threat to the safety of people and property particularly in urban agglomerations, where water supply systems are located within roadway, constituting an element of an underground utility, as well as in areas of compact settlement [13]. The threat emerges as a result of the particles being washed out from the soil skeleton during the breakage of an underground pipe which can lead to the formation of empty spaces beneath the ground surface and contribute to the creation of depression or holes in the Earth's surface (suffosion processes) $[1,4,9]$. Such incidents took place worldwide and produced detrimental social and economical effects [22]. Occurrence of internally unstable soils, especially in the range of the loess plateau [2] as well as a high failure intensity rate of water supply systems, compared to other countries $[15,16,18,19]$, are factors which increase the risk of the emergence of such a problem in Poland.

(*) Tekst artykułu w polskiej wersji językowej dostępny w elektronicznym wydaniu kwartalnika na stronie www.ein.org.pl 
One of the proposals on how to reduce negative consequences of suffosion phenomena following a potential water supply damage is retaining so-called protection zones near the pipes, with all the decisions regarding their use taken exclusively by the system operator [11, 14]. To define the size of such zones seems a difficult task, taking into account the complex character of the phenomenon in question $[3,10$, 27]. During the breakage of an underground water supply there are three fundamental interconnected processes: pressure water flow in a closed pipe, water effluence through a leak and a water flow in a porous medium. They can be characterised by multiple parameters comprising values which are independent (e.g. water pipe diameter), mutually interdependent within one process (e.g. dependence between the volume of the water flow in a water pipe and the water pipe pressure level), as well as affecting each other in various processes (e.g. the speed of water flowing out through a leak affects the speed of the water flow in the ground). Another obstacle is the fact that certain parameters are variable in space or time (e.g. soil hydraulic conductivity) or depend on external factors (e.g. water viscosity index depending on the temperature). Furthermore, connections between the parameters of the processes can be described by means of complex dependencies - for instance water movement in the ground can be represented with the Richards equation [23], which is a second order partial differential equation. What can pose another problem is the process of the soil particles being washed out and transferred with water flowing out of a water pipe after its breakage. Due to the obstacles mentioned above, the analysis aiming at determining the size of protection zones should be performed gradually based on successive field studies, laboratory and numerical research.

The article presents the results of the first stage of the research eventually focused on determining the size of a protection zone around the area where a water pipe is particularly exposed to leakage. The first stage of the investigations covers (1) the assessment of an average distance between the place of water effluence on the soil surface and the place of the water failure for 4 different areas of leak and 11 values of hydraulic pressure head in the pipe, (2) the initiatory assessment of the protection zone dimensions for analysed soil conditions, (3) the analysis of dependence between the time of water effluence on the soil surface after a failure of a buried water pipe and the leak area as well as the hydraulic pressure head in the pipe. The scope of the article comprises laboratory tests and statistical analysis. The research was carried out preserving geometrical and kinematic similarity [12]. Obtained results are initial and oriented towards further stages of laboratory research comprising dynamic similarity.

\section{Methodology}

The research presented in the article is twofold. The first part consists in laboratory simulation of water supply system breakage, conducted on a laboratory setup and reflecting natural operation conditions scaled to $1: 10$. The second part embraces statistical analysis of the laboratory test results including the average distance between the point of water effluence on the sand surface and the leak of the pipe as well as time of this effluence.

Laboratory tests required constructing the setup (Fig. 1). It consisted of a water supply pipe 1 buried in medium sand filling a $1.5 \mathrm{~m}$ $\times 1.5 \mathrm{~m} \times 0.5 \mathrm{~m}$ box 2 . The sand was manually compacted in twocentimetre layers according to closely prearranged processes. During the laboratory tests the following sand parameters were determined (tab. 1 and 2):

- article-size distribution - using a sieve analysis on the basis of the standard [21],

- degree of compaction - using the standard Proctor test - the method No 1 given in the standard [21] (a small cylindrical mould $-113 \mathrm{~mm}$ in the inner diameter, 3 soil layers, 25 drops of 2,5-kilogram hammer, $320 \mathrm{~mm}$ of drop distance),
Table1. Results of a sieve analysis

\begin{tabular}{|c|c||}
\hline Particle size $d, \mathrm{~mm}$ & Content, $\%$ \\
\hline $4<d$ & 8.97 \\
\hline $3.15<d \leq 4$ & 2.17 \\
\hline $2<d \leq 3.15$ & 4.2 \\
\hline $1.4<d \leq 2$ & 3.66 \\
\hline $1<d \leq 1.4$ & 3.63 \\
\hline $0.8<d \leq 1$ & 3.83 \\
\hline $0.5<d \leq 0.8$ & 17.74 \\
\hline $0.25<d \leq 0.5$ & 35.67 \\
\hline $0.125<d \leq 0.25$ & 15.06 \\
\hline$d \leq 0.125$ & 5.03 \\
\hline
\end{tabular}

Table 2. Parameters of compacted sand

\begin{tabular}{||c|c||}
\hline Parameter & Value of parameter \\
\hline Degree of compaction & $0.93 \div 0.94$ \\
\hline Porosity & 0.26 \\
\hline Saturated conductivity, $\mathrm{m} / \mathrm{s}$ & $1.4 \cdot 10^{-4}$ \\
\hline Volumetric water content, $\%$ & $3.89 \div 5.20$ \\
\hline
\end{tabular}

- porosity - using a Le Chatelier flask [22],

- saturated conductivity - using the GeoN permeameter (Geonor$\operatorname{dic}$ AB, Sweden),

- volumetric water content - measured before each simulation using a TDR-meter (EASY-TEST, Lublin, Poland).

One end of the pipe 1 (Fig.1) extending from the box 2 was linked through a rubber hosepipe 3 to a collection container 6 placed at a assumed height. The other end of the pipe 1 directed water to a floor drain through a rubber hosepipe 8 . The pipe consisted of two equal length parts connected by a bell-and-spigot joint (9). Drain 10 installed at the bottom of the box 2 enabled the outflow of excess water after each trial.

The experiment consisted in introducing water under pressure into a damaged water supply pipe so as to produce controlled leakage. First, all valves were closed and water was poured into the container 6 above the assumed level. Next, the valves were opened and the deaeration process took place. When water in container 6 reached the assumed level, valve 7 was closed and the end of pipe 1 from the side of feeding point was pulled in the opposite direction resulting in the loosening of the bell-and-spigot joint 9 . After the emergence of water on the sand surface valve 4 was closed. The next step was to determine the size of the soil surface cavity and its location in relation to the leak in the water supply pipe. An important element of the laboratory setup was the holder 11, installed inside the box on the supply side of the pipe 1 (Fig. 2). The holder enabled the same width of the leak in every repetition of an experiment.

The tests were conducted for 4 different areas of leaks ensuing due to loosening of the pipe connection $-4.71 \mathrm{~cm}^{2}, 5.58 \mathrm{~cm}^{2}, 9.42 \mathrm{~cm}^{2}$ and $12.25 \mathrm{~cm}^{2}$. The width of the leak between a spigot end and a socket end of the pipe equalled $15 \mathrm{~mm}$ for each experiment repetition, while the inner pipe diameter changed $(10 \mathrm{~mm}, 13 \mathrm{~mm}, 20 \mathrm{~mm}$ and $26 \mathrm{~mm}$ ). Internal water pressure in the pipe varied from 31.9 to 58.8 $\mathrm{kPa}$ (from 3.25 to $6.0 \mathrm{~m} \mathrm{H}_{2} \mathrm{O}$ ) depending on the height of container 6 and the water level in it.

Moist sand being in the area around a leak and between a leak and a place of water effluence on the sand surface was replaced by dry sand and compacted after each experiment. Moreover, replacement of the whole sand was performed after a series of experiments for the same leak area. 


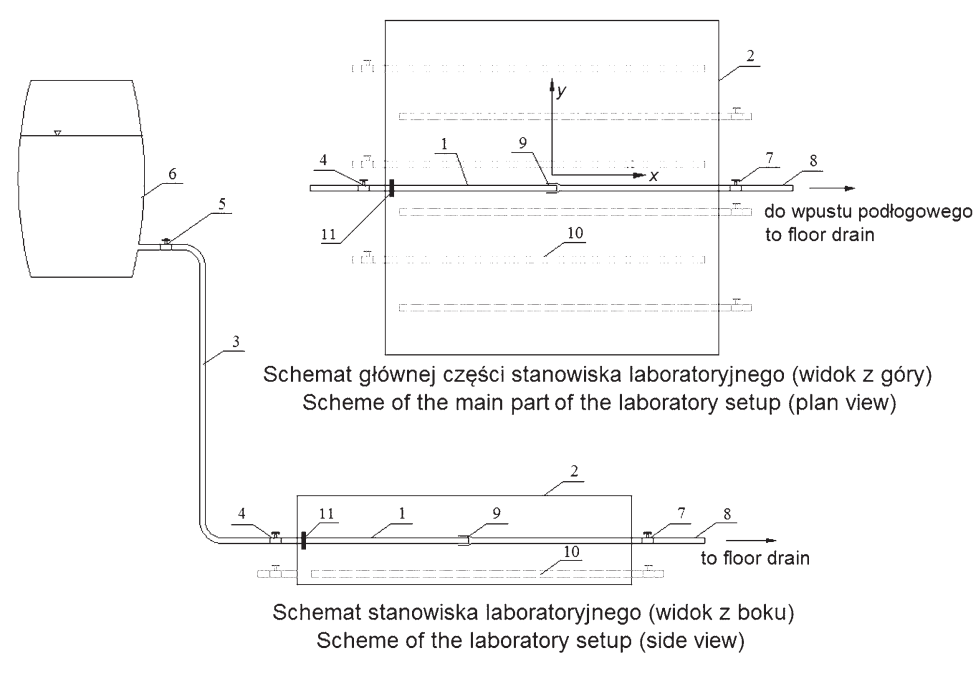

Fig. 1. Scheme of laboratory setup for physical simulation of water supply damage [11]: 1 - water supply pipe, 2 - box filled with sand, 3 -rubber hosepipe from the feeding side, 4,5-cut-off valve on the feeding side, 6 - water container, 7 -cut-off valve on the outflow side, 8 -rubber hosepipe inserted into floor drain, 9 - belland-spigot joint, 10 -drainage, 11 -holder

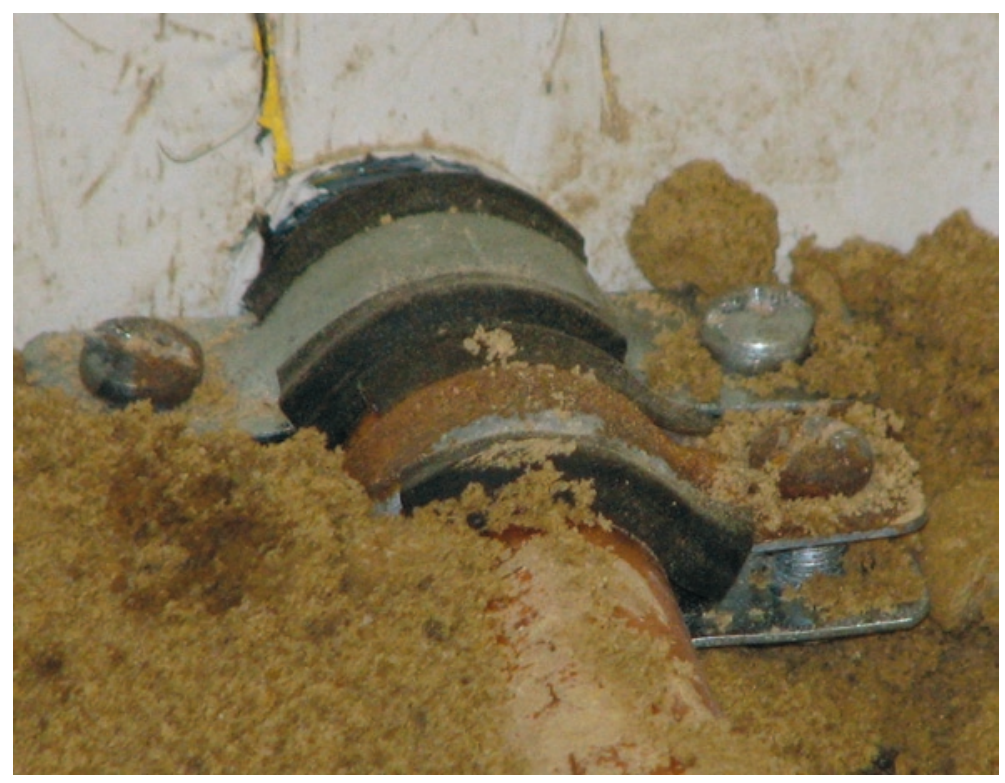

Fig. 2. Holder enabling the same width of leak after each loosening of pipe connection

The entire experiment, starting from the deareation to the moment of water effluence on the soil surface, was recorded by a video camera and documented photographically. Altogether, there were 105 successful trials carried out.

Obtained laboratory test results allowed to determine anticipated values of the distance between the place of the water effluence on the soil surface and pipe leak after the breakage of the water supply pipe, based on statistical estimations calculated with Statistica 10 software (StatSoft, Inc.). The first step of the analysis was descriptive statistics $[17,26]$ comprising measures of central tendency (arithmetic mean, mode and median) as well as measures of dispersion and breakage the shape of distribution (standard deviation, skewness, kurtosis). In the cases where values obtained in laboratory trials were not close to normal distribution, it was examined whether the laboratory test result logarithms can be characterised by it. Distribution normality of the results as well as their logarithms was verified with the Kolmogorov-Smirnov normality test modified by Liliefors and Shapiro-Wilk [6]. Calculations were conducted for all the data obtained in laboratory trials (excluding extreme values) without any divisions and for the data divided per leak area and hydraulic pressure in the pipes.

The results provided the base for determining the indicative range of the protection zone around the leakage through defining ranges of tolerance with the confidence level of $95 \%$ and $99 \%$. All the results regarding the distance between the water effluence on the sand surface and the place on the sand surface located directly above the leak were taken into consideration. With regards to statistical calculations, the lower tolerance limit can take a negative number, though it is inconsistent with the definition of distance. That is why in calculations 0 value was assumed for the lower tolerance limit, i.e. the place of water effluence on the soil surface located closest to the leak is the area situated directly above the leak, which corresponds to the real conditions. The determined upper tolerance limit marks the radius of the circular protection zone, whose centre is located directly above the place of the leak.

The next research stage was the analysis of the results of measurements of time between the loosening of a pipe connection and an effluence of water on the soil surface. As in the case of a distance, data distributions were verified with the Kolmogorov-Smirnov normality test modified by Liliefors as well as with the Shapiro-Wilk normality test. Next, an influence of the leak area and the hydraulic pressure head in the pipe on time of water effluence was evaluated on the basis of a linear, exponential and power regression model.

\section{Results and discussion}

Summary statistics of distances between the water effluence on the sand surface and the place on the sand surface located directly above the leak obtained as a result of laboratory study are compiled in Tables 3-5.

Measures compiled in Table 3 indicate that all the values of the analysed distance examined together with no division are characterised by the distribution different from normal. Distribution of logarithmized distance values, however, is approximate to normal (Fig. 3) which is proved by normality tests with 95 per cent confidence level. The average distance between the water effluence on the soil surface and the place of the leakage obtained in laboratory study does not amount to $30.60 \mathrm{~cm}$, as

Table 3. Summary statistics of all distances registered on the soil surface between water effluence and the place of the

\begin{tabular}{|c|c|c|c|c|c|c|c|c|}
\hline \multirow{2}{*}{$\begin{array}{c}\text { Number of } \\
\text { measurements } n\end{array}$} & \multicolumn{3}{|c|}{ Distance } & \multirow{2}{*}{ Mode } & \multirow{2}{*}{ Median } & \multirow{2}{*}{$\begin{array}{l}\text { Standard } \\
\text { deviation }\end{array}$} & \multirow{2}{*}{ Skewness } & \multirow{2}{*}{ Kurtosis } \\
\hline & $\max$ & mean & $\min$ & & & & & \\
\hline- & $\mathrm{cm}$ & $\mathrm{cm}$ & $\mathrm{cm}$ & $\mathrm{cm}$ & $\mathrm{cm}$ & $\mathrm{cm}$ & - & - \\
\hline 105 & 59.00 & 30.60 & 9.00 & Multiple & 29.00 & 12.64 & 0.52 & -0.60 \\
\hline
\end{tabular}

implied by Table 3, but to $28.18 \mathrm{~cm}$, constituting the result of number 10 raised to the power of the logarithm arithmetic mean of measured distances.

None of the distributions whose measures are presented in Table 4 were found normal. Dependencies between the mean, median and mode as well as positive skewness values indicate that the obtained 


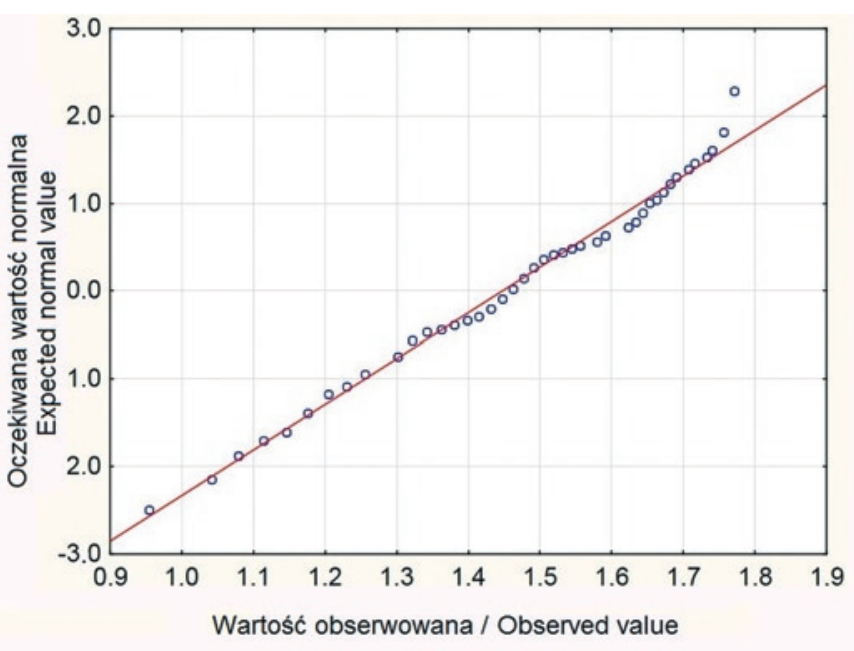

Fig. 3. Normality graph of the logarithm distribution for measured distances

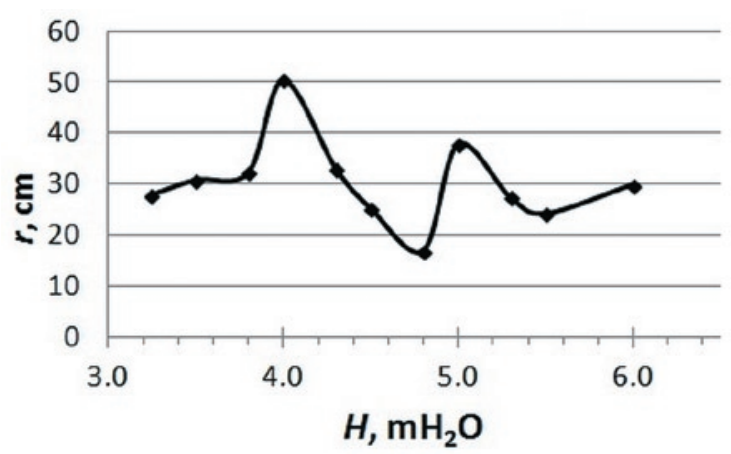

Fig. 4. Correlation between water pressure in pipe $H$ and distance $r$ on the ground surface between water effluence and pipe leak

effluence and the water pipe breakage in laboratory tests for the pressure values of $H=3.25 \mathrm{~m} \mathrm{H}_{2} \mathrm{O}$ and $H=5.30 \mathrm{~m} \mathrm{H}_{2} \mathrm{O}$ is in accordance with the mean presented in Table $5(28.00 \mathrm{~cm}$ and $27.45 \mathrm{~cm}$ respectively), whereas in the case of values of $H=3.50 \mathrm{~m} \mathrm{H}_{2} \mathrm{O}$ and $H=3.80$ $\mathrm{m} \mathrm{H}_{2} \mathrm{O}$ it is $30.90 \mathrm{~cm}$ and $32.36 \mathrm{~cm}$ respectively, which is a result of the data being expressed as logarithms. As far as the remaining pressure values are concerned, it can be assumed that the average effluence distance is in accordance with the arithmetic mean, but since the results obtained for those values are not close to normal (being irregular in all the cases), it should be borne in mind that the average will not be an efficient estimator [17]. Similarly to the analysis of the influence of leak area on the effluence distance af-

results are of a positively asymmetric distribution for all leak areas analysed in laboratory tests. Therefore, it is the mode value that should be assumed as the average distance value obtained for particular leak areas in tests, not the arithmetic mean, which is common the case in normal distribution. No regularities in the relation between the leak area and the distance to the effluence point occurred were observed.

Among 11 distributions whose measures are presented in Table 5, only 2 are close to normal (for $H=3.25 \mathrm{~m} \mathrm{H}_{2} \mathrm{O}$ and $H=5.30 \mathrm{~m} \mathrm{H}_{2} \mathrm{O}$ ), whereas 2 are close to normal after logarithmizing data (for $H=3.50$ $\mathrm{m} \mathrm{H}_{2} \mathrm{O}$ and $H=3.80 \mathrm{~m} \mathrm{H}_{2} \mathrm{O}$ ). The average distance between the water ter potential breakage, no regularities in the relations between the pipe water pressure and the distance itself were observed (Fig. 4).

In 105 physical simulations of water supply failures carried out in a laboratory there were no cases of water effluence directly above the leakage. This necessitated determining the zone on the soil surface of probable water effluence after an underground water system failure through the estimation of the upper tolerance limit. Due to the fact that previous analysis showed that the logarithms of all distances obtained during laboratory tests, examined without division, are of a normal distribution, tolerance intervals were determined for the logarithms of those values (Table 6).

Conducted measurements show that the protection zone radius, depending on accepted statistical assumptions, is found within the range from $46.5 \mathrm{~cm}$ to $77.1 \mathrm{~cm}$ in laboratory conditions (Fig. 5), i.e. the zone of the radius $46.5 \mathrm{~cm}(4.46$ $\mathrm{m}$ in real conditions) will cover 70 per cent of the water effluence points with a 95 per cent confidence level, whereas the zone of a $77.1 \mathrm{~cm}$ long radius $(7.71$ $\mathrm{m}$ in real conditions) will cover 95 per cent of the ef- 
Table 6. Upper tolerance limit for distances measured on soil surface between water effluence and breakage

\begin{tabular}{||l|c|c|c|c|c|c|c||}
\hline \hline Tolerance level [\%] & 70 & 75 & 80 & 85 & 90 & 95 \\
\hline Confidence level [\%] & \multicolumn{7}{|c||}{95} \\
\hline Logarithm of the upper tolerance level [log cm] & 1.66 & 1.69 & 1.72 & 1.75 & 1.80 & 1.86 \\
\hline Upper tolerance limit [cm] & 46.5 & 49.2 & 52.5 & 56.7 & 62.7 & 73.2 \\
\hline Confidence level [\%] & \multicolumn{7}{|c||}{99} \\
\hline Logarithm of the upper tolerance level [log cm] & 1.68 & 1.70 & 1.73 & 1.77 & 1.81 & 1.89 \\
\hline Upper tolerance limit [cm] & 47.8 & 50.73 & 54.3 & 58.9 & 64.6 & 77.1 \\
\hline
\end{tabular}

Analysis of the time measurements results indicated that the obtained values are not characterised by the normal distribution in any cases - neither for data examined together with no division nor for data divided according to hydraulic pressure, nor for data divided according to leak area. The normal distribution of logarithmized data was obtained for rare cases - for $F=4.71$ $\mathrm{cm}^{2}$ and $F=9.42 \mathrm{~cm}^{2}$ for data divided according to leak area and for $H=4.30 \mathrm{~m}$ $\mathrm{H}_{2} \mathrm{O}$ and $H=5.50 \mathrm{~m} \mathrm{H}_{2} \mathrm{O}$ for data divided according to hydraulic pressure.

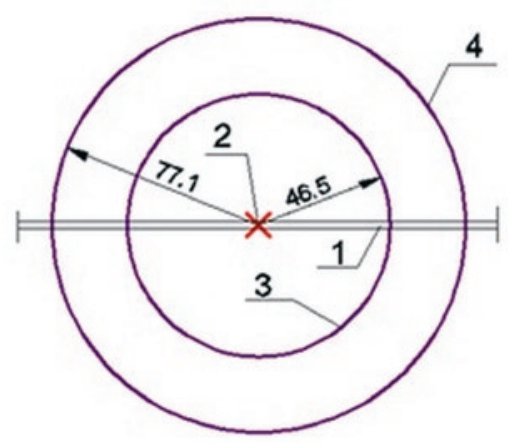

Fig. 5. Minimal and maximal (depending on statistical assumptions) protection zone range: 1 -water supply, 2 - leak, 3 - protection zone range for a 95 per cent confidence level and 70 per cent tolerance level, 4 - protection zone range for a 99 per cent confidence level and 95 per cent tolerance level

fluence points with a 99 per cent confidence level. The increase of the confidence level from $95 \%$ to $99 \%$ results in the growth of the zone radius by about $1 \div 4 \mathrm{~cm}$ in laboratory conditions. It ought to be mentioned, however, that the difference increases with the increase of the tolerance level. It is the change of the tolerance level which is of bigger impact on the value of the zone radius, as with the increase of the parameter in question from $70 \%$ to $95 \%$, the radius rises by $26.7 \mathrm{~cm}$ with a $95 \%$ confidence level and by $29.3 \mathrm{~cm}$ with a $99 \%$ confidence level.

Table 7. Time of water effluence on sand surface starting from the moment of failure occurrence, in dependence on leak area and hydraulic pressure head

\begin{tabular}{|c|c|c|c|c||}
\hline \multirow{2}{*}{$\begin{array}{c}H \\
{\left[\mathrm{~m} \mathrm{H}_{2} \mathrm{O}\right]}\end{array}$} & \multicolumn{4}{|c||}{ Effluence time $t[\mathrm{~s}]$ for area of leak } \\
\cline { 2 - 5 } & $4.71 \mathrm{~cm}^{2}$ & $5.58 \mathrm{~cm}^{2}$ & $9.42 \mathrm{~cm}^{2}$ & $12.25 \mathrm{~cm}^{2}$ \\
\hline 3.3 & 22.10 & - & 65.67 & 91.67 \\
\hline 3.5 & 116.03 & 26.15 & 41.08 & 81.25 \\
\hline 3.8 & 65.98 & 117.23 & 15.50 & 3.01 \\
\hline 4.0 & 13.51 & 21.50 & 51.11 & 37.98 \\
\hline 4.3 & 14.49 & 4.07 & 29.18 & 82.53 \\
\hline 4.5 & 7.50 & 8.57 & 61.50 & 19.50 \\
\hline 4.8 & 26.00 & 15.89 & 18.51 & 4.00 \\
\hline 5.0 & 61.55 & 1.00 & 10.00 & 1.54 \\
\hline 5.3 & 10.01 & 1.99 & 8.12 & 3.87 \\
\hline 5.5 & 5.50 & 37.20 & 9.03 & 2.06 \\
\hline 6.0 & 9.47 & 15.00 & 2.52 & 2.50 \\
\hline
\end{tabular}

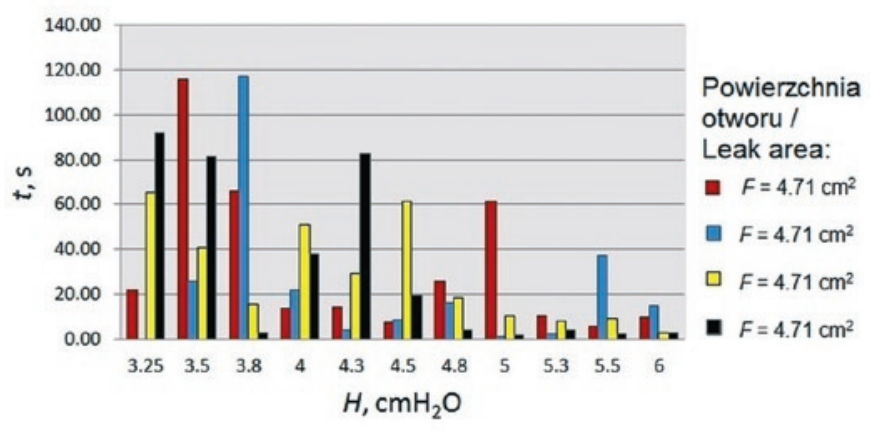

Fig. 6. Dependence between time of water effluence on soil surface after pipe loosening and hydraulic pressure head (H) for different leak areas (F)

The arithmetic means of time of water effluence measurement values for different hydraulic pressures in a pipe and leak areas are shown in Table 7. The means are not efficient estimators because of the data distribution irregularity, so they should be treated as indicative only.

Analyzing the obtained results (Tab. 7) it can be noticed as per the expectations, that higher place of the water supply container results in tendency of time of water effluence on the sand surface to be lower. The mentioned dependence is clearly visible in the bar chart (Fig. 6). However it should be emphasized, that unambiguous evaluation of kind of trend is difficult. The coefficient of determination for all considered models (linear, exponential and power) was low (Tab. 8).

Table 8. Coefficient of determination $R^{2}$ for linear, exponential and power regression model defining function $t(H)$

\begin{tabular}{|c|c|c|c||}
\hline \multirow{2}{*}{$\begin{array}{c}\text { Leak area } \\
F\end{array}$} & \multicolumn{3}{|c|}{$R^{2}$ for regression model } \\
\cline { 2 - 4 } & linear & exponential & power \\
\hline $4.71 \mathrm{~cm}^{2}$ & 0.23 & 0.32 & 0.25 \\
\hline $5.58 \mathrm{~cm}^{2}$ & 0.15 & 0.13 & 0.20 \\
\hline $9.42 \mathrm{~cm}^{2}$ & 0.56 & 0.68 & 0.52 \\
\hline $12.25 \mathrm{~cm}^{2}$ & 0.53 & 0.57 & 0.53 \\
\hline
\end{tabular}

Any regularity between the time of water effluence and the leak area in a loosening pipe was noticed during the analysis of the data shown in Table 7 and in Fig. 6.

\section{Summary and conclusions}

Failures and leakages are inextricably linked to the use of water supply systems and, apart from economic loss, they generate a real risk of dangerous suffosion phenomena in the soil. In order to minimise their harmful effects, it has been suggested that protection zones 
of a limited land development should be retained around water supply elements which are particularly subject to leakages. Currently there are no guidelines on how to determine the range of such zones, even though water supply system operators demonstrate keen interest in this sort of data.

Determination of the size of protection zones is a significantly time-consuming task of considerable difficulty due to the complexity of the effects accompanying underground water supply system failure. The sheer number of parameters influencing the direction as well as the speed of water movement in the ground together with interconnections between those parameters necessitate the division of the research into stages, beginning with the most basic. Research constituting the first stage presented in this article proved to be highly valuable with respect to further study. What it did was enabling the recognition of the obstacles that had to be overcome during the physical simulation of a water supply system breakage and setting direction for further research.

Statistical analysis of the results obtained at the first stage of the laboratory tests performed with the use of geometric and kinematic probability was also found promising and allowed preliminary estimation of the range of the protection zone. The range in question is based predominantly on the obtained distances between the wa- ter effluence on the surface of the soil and breakage, and to a lesser extent, on statistical assumptions. Moreover, the conducted analyses confirmed clear dependence between the time of water effluence on soil surface after a waterpipe failure and the hydraulic pressure in a pipe. However, values obtained as a result of time measurements were not characterized by the normal distribution, so they should be treated as indicative only. Thus, in order to achieve the best possible results of estimating both the zone range and parameters influencing the time of water effluence on soil surface, the quality of the laboratory research should not be neglected above all. It is, therefore, suggested that in order to reach normal result distribution, dimensional analysis preceding laboratory study should be repeated, and ought to focus on extending the number of parameters influencing the studied process, together with increasing the number of simulated breakages repetitions in steady conditions.

\section{Acknowledgements}

The article has been financed through statutory activities of Department of Water Supply and Wastewater Disposal of Environmental Engineering Faculty of Lublin University of Technology

\section{References}

1. Bendahmane F., Marot D., Rosquoët F., Alexis A. Experimental parametric study of suffusion and backward erosion. International Journal of Geotechnical and Geoenvironmental Engineering 2008; 134 : 57-67, http://dx.doi.org/10.1061/(ASCE)1090-0241(2008)134:1(57).

2. Bernatek A. Rola sufozji w rozwoju rzeźby - stan i perspektywy badań. Przegląd Geograficzny 2014; 86: 53-76, http://dx.doi.org/10.7163/ PrzG.2014.1.4.

3. Błażejewski R., Maćkowski S. Eksfiltracja, infiltracja i sufozja przez szczeliny uszkodzonych kanałów ściekowych. In: J. Dziopak, D. Słyś, A. Stec (eds.): Materiały II Ogólnopolskiej Konferencji Naukowo-Technicznej Infrastruktura Komunalna a Rozwój Zrównoważony Terenów Zurbanizowanych. INFRAEKO 2009: 19-31.

4. Bonelli S., Marot D. On the modelling of internal soil erosion. The 12th International Conference of International Association for Computer Methods and Advances in Geomechanics (IACMAG) 1-6 October, Goa, India 2008.

5. Denczew S. The reliability, safety and risks of water supply system operation versus critical infrastructure. Eksploatacja i Niezawodnosc Maintenance and Reliability 2007; 2: 15-21.

6. Dobosz M. Wspomagana komputerowa analiza statystyczna wyników badań. Warszawa: Akademicka Oficyna Wydawnicza EXIT, 2001.

7. Hotloś H. Analiza uszkodzeń i kosztów naprawy przewodów wodociągowych w okresie zimowym. Ochrona Środowiska 2009; 31: 41-48.

8. Hotloś H. Metodyka i przykłady prognozowania kosztów naprawy przewodów wodociągowych. Ochrona Środowiska 2006; $28: 49-54$.

9. Indraratna B., Nguyen V. T., Rujikiatkamjorn C. Assessing the Potential of Internal Erosion and Suffusion of Granular Soils. Journal of Geotechnical and Geoenvironmental Engineering 2011; 137: 550-554, http://dx.doi.org/10.1061/(ASCE)GT.1943-5606.0000447.

10. Iwanek M. Zjawisko sufozji jako skutek awarii infrastruktury wodociągowej lub kanalizacyjnej. Przegląd literatury. In: K. Kuś, F. Piechurski F. (eds.): Nowe Technologie w Sieciach i Instalacjach Wodociągowych i Kanalizacyjnych. Gliwice 2014, 57-78.

11. Iwanek M., D. Kowalski D., Kowalska B., Hawryluk E., Kondraciuk K. Experimental investigations of zones of leakage from damaged water network pipes. In: C. A. Brebbia, S. Mambretti (eds.): Urban Water II. WIT Transactions on the Built Environment 2014; 139; Southampton, Boston, UK: WIT Press: 257-268, http://dx.doi.org/10.2495/uw140221.

12. Iwanek M., Malesińska A. Zastosowanie teorii podobieństwa w modelowaniu awarii sieci wodociągowych. Gaz, Woda i Technika Sanitarna 2015; 3: 82-86.

13. Khomenko V. P. Suffosion hazard: today's and tomorrow's problem for cities. In: Culshaw, M. G., Reeves, H. J., Jefferson, I. \& Spink, T. W. (eds.) Engineering geology for tomorrow's cities, Geological Society, London: Engineering Geology Special Publication, 2009.

14. Kowalski D., Jaromin K. Metoda wyznaczania zasięgu strefy ochrony wodociągowych przewodów tranzytowych. Proceedings of EC Opole 2011; 4: 419-424.

15. Kowalski D., Kowalska B., Kwietniewski M., Sygacz - Adamska J. Analiza bilansu wody oraz awaryjności wybranego systemu dystrybucji wody. In: Z. Dymaczewski, J. Jeż - Walkowiak (eds.): Zaopatrzenie w wodę, jakość i ochrona wód, tom 2, Polskie Zrzeszenie Inżynierów i Techników Sanitarnych, Oddział Wielkopolski, Poznań 2012: 77-92.

16. Kowalski D., Miszta-Kruk K. Failure of water supply networks in selected Polish towns based on the field reliability tests. Engineering Failure Analysis 2013; 35: 736-742, http://dx.doi.org/10.1016/j.engfailanal.2013.07.017.

17. Krysicki W., Bartos J., Dyczka W., Królikowska K., Wasilewski M. Rachunek prawdopodobieństwa i statystyka matematyczna w zadaniach, cz. II Statystyka matematyczna. Warszawa: Wydawnictwo Naukowe PWN, 2011

18. Kutyłowska M., Hotloś H. Failure analysis of water supply system in the Polish city of Głogów. Engineering Failure Analysis 2014; 41: 2329, http://dx.doi.org/10.1016/j.engfailanal.2013.07.019.

19. Kwietniewski M. Awaryjność infrastruktury wodociągowej i kanalizacyjnej w Polsce w świetle badań eksploatacyjnych. XXV Konferencja Naukowo-Techniczna Awarie Budowlane, 24-27 maja 2011: 127-140.

20. Myślińska E. Laboratoryjne Badania Gruntów. Warszawa: Wydawnictwo Naukowe PWN, 1998. 
21. PN-88/B-04481 Grunty budowlane. Badania próbek gruntu - Building soils. Laboratory tests.

22. Ragozin A. L. Basic principles of natural hazard risk assessment and management. In: R. Oliveira, L. F. Rodrigues, A. G. Coehlo, A. P. Cunha (eds.): Proceedings of the 7th International Congress of the International Association of Engineering Geology 3, Lisbon, Portugal, A. A. Balkema, Rotterdam 1994: 1277-1286.

23. Richards L.A. Capillary conduction of liquids through porous mediums. Physics 1931; 1: 318-333, http://dx.doi.org/10.1063/1.1745010.

24. Romano M., Kapelan Z. Geostatistical techniques for approximate location of pipe burst events in water distribution systems. Journal of Hydroinformatics 2013; 15.3: 634-635, http://dx.doi.org/10.2166/hydro.2013.094.

25. Siwoń Z., Cieżak W., Cieżak J. Praktyczne aspekty badań strat wody w sieciach wodociągowych. Ochrona Środowiska 2004; 26/4: 25-30.

26. Sobczyk M. Statystyka. Warszawa: Wydawnictwo Naukowe PWN, 2014.

27. Vlahovič M. Dispersion of results during determination of possibilities of internal erosion phenomenon using the empirical methods. Proceedings of 5th International Congress International Association of Engineering Geology 2, Buenos Aires 1986: 1037-1040.

28. Żaba T., Langer A. Monitoring strat wody elementem ograniczenia kosztów działalności przedsiębiorstwa. Napędy i sterowanie 2012; 4:100-103.

\section{Małgorzata IWANEK \\ Beata KOWALSKA}

Department of Water Supply and Wastewater Disposal

Faculty of Environmental Engineering

Lublin University of Technology

ul. Nadbystrzycka 40 B, 20-816 Lublin, Poland

\section{Elżbieta HAWRYLUK}

Kamil KONDRACIUK

graduates

Lublin University of Technology, Lublin, Poland

E-mails:M.Iwanek@wis.pol.lublin.pl, B.Kowalska@pollub.pl 